\title{
Unusual echocardiographic appearance of left ventricular thrombi in a patient with dilated cardiomyopathy
}

\author{
Muhammad Muzaffar Mahmood, ${ }^{1}$ Shahid Mahmood ${ }^{2}$
}

${ }^{1}$ Department of Cardiology, James Cook University Hospital, Middlesbrough, UK ${ }^{2}$ Department of Cardiology, Sunderland Royal Hospital, Sunderland, UK

\section{Correspondence to} Dr Muhammad Muzaffar Mahmood,

muzafar.mahmood@gmail.com

Accepted 28 September 2014

CrossMark

To cite: Mahmood MM, Mahmood S. BMJ Case Rep Published online: [please include Day Month Year] doi:10.1136/bcr-2014204416

\section{DESCRIPTION}

A 69-year-old woman presented with 3-week history of increasing dyspnoea, orthopnoea and weight gain. She denied any history of chest pain, fever or upper respiratory tract symptoms. The patient's medical history was unremarkable. She was a non-smoker with minimal alcohol intake. Physical examination revealed pitting ankle oedema and raised jugular venous pressure. Heart sounds were normal and chest examination revealed fine crepitations at both lung bases. ECG showed normal sinus rhythm, poor $\mathrm{R}$ wave progression in anterior chest leads and $1 \mathrm{~mm} \mathrm{ST} \mathrm{segment} \mathrm{elevation}$ in lateral chest leads with associated $\mathrm{T}$ wave inversion. Troponin Twas 1995 ng/L (normal (N) 0-13) with a second value of $1629 \mathrm{ng} / \mathrm{L}$. NT-ProBNP was $5253 \mathrm{ng} / \mathrm{L}$ (N 0-125). Serum creatinine was $101 \mu \mathrm{mol} / \mathrm{L}$ (N 58-96). Chest X-ray showed cardiomegaly with clear lung fields. A transthoracic echocardiogram revealed a normal sized left ventricle with global hypokinaesia and severe impairment of systolic function. Within the left ventricular (LV)

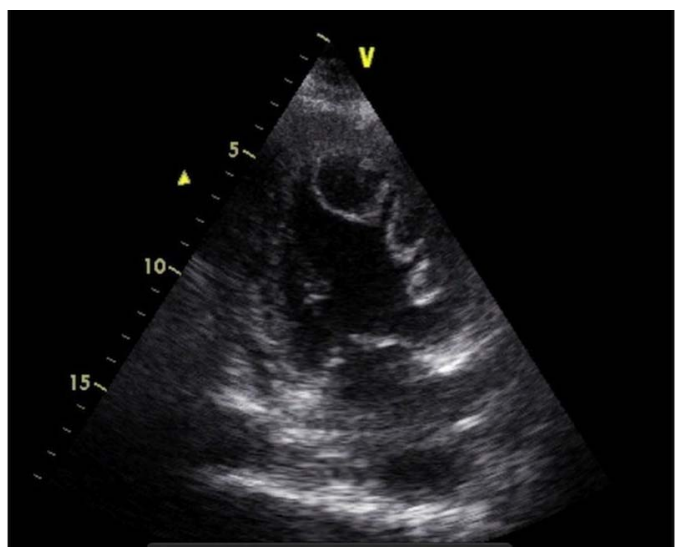

Figure 1 Transthoracic echocardiogram. A modified apical two-chamber view revealed three spherical masses with echo lucent centres. cavity, three spherical echo lucent masses were noted attached to the lateral wall (figure 1). These masses likely represented intracardiac thrombi in view of new onset heart failure. The echo lucent centre suggested that the thrombi were relatively new and carried a high risk of systemic embolism. The patient was anticoagulated with warfarin. Heart failure was treated with diuretics, ACE-I and $\beta$-blocker therapy. Coronary angiogram showed unobstructed coronary arteries. A diagnosis of idiopathic dilated cardiomyopathy was made.

The patient was clinically well on a review 6 weeks later and an echocardiogram confirmed resolution of intracardiac thrombi and mild impairment of LV systolic function.

\section{Learning points}

Left ventricular thrombi are common in patients with severe systolic dysfunction. ${ }^{2}$

- Echo lucent left ventricular thrombi may carry a higher than usual embolic potential and anticoagulation is generally indicated. ${ }^{1}$

Contributors MMM wrote the manuscript. SM is the consultant responsible for the patient's care and is the reviewer and guarantor of the content.

Competing interests None.

Patient consent Obtained.

Provenance and peer review Not commissioned; externally peer reviewed.

\section{REFERENCES}

1 Haugland JM, Asinger RW, Mikell FL, et al. Embolic potential of left ventricular thrombi detected by two-dimensional echocardiography. Circulation 1984;70:588-98

2 Sharma ND, McCullough PA, Philbin EF, et al. Left ventricular thrombus and subsequent thromboembolism in patients with severe systolic dysfunction. Chest 2000;117:314-20. 
Copyright 2014 BMJ Publishing Group. All rights reserved. For permission to reuse any of this content visit http://group.bmj.com/group/rights-licensing/permissions.

BMJ Case Report Fellows may re-use this article for personal use and teaching without any further permission.

Become a Fellow of BMJ Case Reports today and you can:

- Submit as many cases as you like

- Enjoy fast sympathetic peer review and rapid publication of accepted articles

- Access all the published articles

- Re-use any of the published material for personal use and teaching without further permission

For information on Institutional Fellowships contact consortiasales@bmjgroup.com

Visit casereports.bmj.com for more articles like this and to become a Fellow 